\title{
MEDIATING JOB SATISFACTION IN REDUCING TURNOVER INTENTION OF NURSE AT RSUD dr. SOEKARDJO TASIKMALAYA
}

\author{
Peni Cahyati \\ Health Polytechnic of the Ministry of Health, Tasikmalaya \\ E-mail : Peni_poltekstsm@yahoo.com
}

\begin{abstract}
The aim of this study was to determine the influence of organizational culture and compensation on job satisfaction and its implications on the intention to move the nurse at the Regional General Hospital dr. Soekardjo Tasikmalaya. The results of this study can be useful practically and theoretically, i.e. as material development management of human resources, especially nurses in order to improve the quality and productivity of hospital services as well as lowering the intention of migration of nurses. The research method uses a quantitative approach, with the nature of this research was descriptive and verification. How to capture data through interviews and questionnaire with the techniques of observation and field Study, with the sampling technique of sampling is simple. The collection of Data in the field is done in 2019. Statistical analysis techniques to test hypotheses using Path Analysis. Based on the results of the analysis, it can be seen that the culture of the organization, compensation, job satisfaction and intentions to move in general is pretty good. There is the influence of organizational culture and compensation as well as job satisfaction simultaneously on work satisfaction, as well as have a negative effect on the intention to move from the nurses in the Regional General Hospital dr. Soekardjo Tasikmalaya.
\end{abstract}

Keywords: Organizational Culture; Compensation; Job Satisfaction; Turnover Intention

\section{MEDIASI KEPUASAN KERJA DALAM MENURUNKAN INTENSI BERPINDAH PERAWAT DI RSUD dr. SOEKARJO TASIKMALAYA}

\begin{abstract}
ABSTRAK. Tujuan dari studi ini adalah untuk mengetahui pengaruh budaya organisasi dan kompensasi terhadap kepuasan kerja serta implikasinya pada intensi berpindah perawat di RSUD dr. Soekardjo Tawmalaya. Hasil studi ini dapat bermanfaat secara praktis maupun teoritis, yaitu sebagai bahan pengembangan manajemen sumber daya manusia, khususnya perawat dalam rangka meningkatkan kualitas dan produktivitas pelayanan rumah sakit serta menurunkan intensi berpindahnya perawat. Metode penelitian menggunakan pendekatan kuantitatif, dengan sifat penelitian deskriptif dan verifikatif. Cara pengambilan data melalui wawancara dan kuesioner dengan teknik observasi dan studi lapangan, dengan teknik sampling pengambilan sampel secara sederhana. Pengumpulan Data di lapangan dilakukan pada tahun 2019. Teknik analisis statistik untuk menguji hipotesis menggunakan Analisis Jalur. Berdasarkan hasil analisis, dapat dilihat bahwa budaya organisasi, kompensasi, kepuasan kerja dan niat untuk bergerak secara umum cukup bagus. Ada pengaruh budaya organisasi dan kompensasi serta kepuasan kerja secara simultan terhadap kepuasan kerja, serta memiliki efek negatif terhadap niat untuk pindah dari para perawat di RSUD dr. Soekardjo Tasikmalaya.
\end{abstract}

Kata kunci: Budaya Organisasi; Kompensasi; Kepuasan Kerja; Intensi Berpindah

\section{INTRODUCTION}

Hospital is a labor-intensive industry consisting of many professionals who work in it, including doctors, nurses, pharmacists, radiologists, nutritionists, and others who demand arrangements that are in accordance with their duties and their respective functions. In its implementation it is regulated by Law, among other things, article 33, paragraph 1 and 2 of the Republic of Indonesia Law Number 44 year 2009 stated that the hospital is expected to have an effective, efficient and responsible organization that consists of (at least) the leader ( head or director, element of medical services, elements of medical aid, elements of medical assistance, the health committee, the medical unit, internal, and also established the Institutions of public Administration and Finance in RS. 19 and RS., is located on Jalan Rumah Sakit
No. 33 Tasikmalaya with a capacity the current bed is 480 beds. Based on the Decree of the Minister of Health of the Republic of Indonesia dated December 15, 1993 No. 1166 / Menkes / SK / XII. 1993 the type of Regional General Hospital dr. Soekardjo is a Class B Non Education Hospital. With the vision is " Becoming a General Teaching Hospital with Excellent Service To be able to carry out complete health services, one of the obligations of a hospital It is implementing standards in accordance with hospital accreditation standards. According to the Decree of the Director General of Health Services Number HK.02.04 / I / 2790/11 concerning Hospital Accreditation Standards, in order to improve the quality of hospital services and face the era of globalization, it is necessary to implement a hospital accreditation system in accordance with international standard services. Competition in the hospital world 
in Indonesia is getting tighter and tighter along with the growing business. Therefore, every hospital is competing to improve the quality and quality of its services to be able to compete with other hospitals (Pemerintah Republik Indonesia, 2014)

One of the problems in human resource management is regarding employees who leave and enter continuously or there is turnover employee before retirement. This is also said by (Halbesleben \& Wheeler, 2008) that the problem of human resources that is often an indicator of the effectiveness of an organization is turnover. If the threat turnover increases, it is necessary to evaluate whether this is due to poor workplace conditions or due to other factors. One of the high-rate turnarounds in the health care industry, in this case hospitals, occurs in nurses because nurses are one of the largest personnel in hospitals. (De Simone, Planta, \& Cicotto, 2018), the standard of turnover optimum of nurses in a hospital is $10 \%$ annually. The high turnover of nurses is due to the high turnover intention of nurses to leave the hospital where this desire is influenced by job satisfaction and the availability of job alternatives outside the organization (Marina, Sugeng, Wahyono, \& Nirbito, 2014).

Factors affecting turnover are nurse divided into two, namely nurse characteristics (age, gender, family background, work experience, motivation, nurse typology, and self-perception) and internal hospital environmental factors (HR management which includes recruitment and selection, socialization, training and development, job performance appraisal, system reward, promotion, transfer and termination of employment, as well as organizational culture, and work comfort (Priatna \& Roswinna, 2019). Turnover is the process by which staff leave a business or organization and that business or organization take their place. The purpose of a turnover is a measure of whether a business or organizational plan to leave their positions or whether the organization plans to remove employees from positions. The intention of Turnover, such a turnover of its own, it can be voluntary or involuntary. The turn of a voluntary happens when employees make the decision to go it alone. Usually, the intention of the foyer happens when employees see an opportunity that is better than his current position. This includes salary, more recognition or a more convenient location. It can also happen when an employee should go to health or family reasons. If the employee plans to voluntarily step down from the position it is also voluntary.

Results of preliminary interviews conducted at the Regional General Hospital dr. Soekardjo Tasikmalaya noted that the problem of turnover employee, especially nurses, causes nurses to become inefficient and effective. Inefficient because the costs of recruiting new nurses, training costs of new nurses, and orientation of new nurses are very high every year. Ineffective because not all of the substitute personnel recruited are ready to work and have good skills nursing so that it takes a long time to be able to serve patients well (Stepen P Robbins \& Judge, 2008). In line with that, the high turnover of nurses can clearly cause a lot of harm to the organization. Some of them, such as an increase in organizational expenditures and discontinuation of patient care (Chitpakdee and Chontawan, 2011), then have an impact on job satisfaction and safety of nurses and other health workers as well as customer satisfaction and loyalty which can affect their perceptions of service quality (Baumann, 2010).

Turnover of nurses at the Regional General Hospital dr. Soekardjo Tasikmalaya shows relatively high fluctuations, reaching an average of $14.83 \%$ each year (RSUD dr. Soekardjo Report, 2018), meaning that if the hospital has 100 nurses, in a year there are 14 to 15 nurses who leave. These data indicate that the turnover rate of nursing personnel at the Regional General Hospital dr. Soekardjo Tasikmalaya is higher than the average turnover of nurses, which is $10 \%$ per year (De Simone et al., 2018). Most of the nurses who leave the hospital for voluntary reasons can be categorized as voluntary changes that can be avoided and cannot be avoided. Reimbursements that should be avoided could be for reasons such as salary, working conditions, employers, or another company that they think is better. Conversely, turnover that is voluntary can be caused by changes in career paths or family factors (Liden, Wayne, Liao, \& Meuser, 2014). In addition, turnover intention to nurses is the intensity of the nurse's desire to leave the hospital where the nurse works (Chen \& Silverthorne, 2005). Intention to leave as the intention of a nurse to make the actual turnover from an organization (Mosadeghrad, 2013). Meanwhile, the changes made by the hospital refer to the results of individual evaluations regarding the continuation of their relationship with the organization and have not yet manifested themselves in actions that must leave the organization (De Simone et al., 2018).

Various studies and literature show that the desire to move a person cannot be separated from two factors or variables that have the potential to relate to or influence the event, namely: job satisfaction and compensation (Riansari et al., 2012). Employees who are not satisfied with their work in a serious level have the potential to leave the organization or company that provided the job for them. Likewise, 
employees who do not receive adequate work compensation can leave the company, especially if other companies promise greater compensation.

Job satisfaction is defined as the level of satisfaction of nurses with their work. Beyond their daily duties to include satisfaction with the team member or leader, satisfaction with organizational policies, and the impact of their work on the personal life of the nurse. Job satisfaction, a measure that cannot be explained as a response to positive emotional responses experienced at work or when present at work. In the same workplace with the same conditions, the factors that help nurses feel comfortable with their work may not apply to other employees. So it is important to have a multidimensional approach to nurse satisfaction, which includes things such as work challenges, pushing to new levels, levels of comfort (short distances, access to work equipment, and appropriate working hours, can be appreciated by direct management, and organization as a whole, competitive Job satisfaction as feelings of support or not support for nurses related to their job or condition (Srivastava \& Kanpur, 2014). Feelings related to work that involve aspects such as salary / salary received, promotion opportunities, relationships with other employees, job placement, type of company organizational structure, and quality of supervision. Meanwhile, feelings related to age, health conditions, abilities, and education (Srivastava \& Kanpur, 2014). Meanwhile, job satisfaction is an attitude that a nurse has towards her job (Kaur, 2015). The aspects of employment are wages, opportunities, promotions, supervision, and colleagues. It also stems from environmental factors such as policies and procedures, affiliated work groups, and working conditions (Kaur, 2015).

Another factor that is thought to cause the nurse's desire to move is the compensation received by the nurse (Riansari, Sudiro, \& Rofiaty, 2012). The issue of compensation is very important because it is a person's main motivation to become an employee and has a significant influence on the enthusiasm and enthusiasm of nurses (Thanos, Pangemanan, \& Rumokoy, 2015). Thus, each organization (hospital) must determine the most appropriate compensation in order to support the achievement of its goals more effectively and efficiently (Riansari etal., 2012). How much compensation is given must be such that it can bind the nurse (Crane, Michenaud, \& Weston, 2016). This is very important because if the compensation component provided is too small compared to other places it can cause nurses to change places (Riansari et al., 2012). Compensation is more than just a regular salary that is paid (Crane, Michenaud, \&
Weston, 2016). Also includes many types of salaries and benefits. Types of compensation include: base salary (wages or hourly wages), sales commissions, overtime pay, overtime pay, salary bonuses, bonus payments, recognition or performance payments, benefits (insurance, policy vacation, pension), stock options, and other benefits non cash.

Another literature review regarding nurse turnover intentions was organizational culture. Organizational culture includes expectations, experiences, philosophies, and organizational values that guide member behavior, and are expressed in members' self-image, working on the inside, interactions with the outside world, and expectations for the future. This culture is based on attitudes, beliefs, customs, and written or unwritten rules that have been developed from time to time and are considered valid. Culture also includes the vision, values, norms, systems, symbols, language, assumptions, beliefs and habits of the organization (Williams \& Nadin, 2012). This research was supported by the results of the researchers' preliminary observations, which show the organizational culture of the Regional General Hospital nurse dr. dr. Soekardjo Tasikmalaya was still relatively low, such as there are still many nurses who say they do not feel they have a job that must be achieved in every job, a culture of cooperation with fellow nurses that is felt is still lacking, and there is still a lack of a culture of collaboration with leaders (Chung, 2011). The organizational culture which was still low is also seen in the dominant values which are indicated by the number of nurses who claim that they lack the culture to continue to improve in sharing knowledge/ experiences (Baker \& Sinkula, 2009), quality of service, increasing attendance and efficiency at work (Chu, Leino, Pflum, \& Sue, 2016). Likewise with the philosophy of work as indicated by the number of nurses who stated that they lacked confidence in continuing to increase their ability as nurses at the Regional General Hospital. (Chu, Leino, Pflum, \& Sue, 2016).

The results of the research can develop the Science of Management in the care, especially that associated with job satisfaction and turnover of nurses and can provide information to academics, both teaching and nursing students, to the process of scientific thinking, especially in understanding the factors that affect job satisfaction and turnover shift.

\section{METHOD}

In this research, the independent variables are organizational culture and compensation, while the dependent variables are job satisfaction and turnover 
intention. The research method uses a quantitative approach, which is a method related to understanding how something is constructed, built or works. Each construct is broken down into components and indicators. The nature of this research is descriptive and verification. Descriptive research is research that aims to obtain a description of the characteristics of the variables. The nature of verification research basically wants to test the truth of the hypothesis through data collection in the field. Where in this study will be tested whether organizational culture and compensation have an effect on job satisfaction and turnover intention.

The population in this research were 315 nurses. Determination of the sample size of respondents can be done using the Slovin formula (Umar, 2008).

$$
n=\frac{N}{1+N e^{2}}
$$

Where: $\mathrm{n}=$ Sample size

$\mathrm{N}=$ Number of population

$\mathrm{e}=$ Percent of uncertainty allowance with an error rate of $5 \%$

The total population is 315 nurses, with an allowance level of $5 \%(0.05)$ or it can be stated that the level of accuracy is $95 \%(0.95)$ so that the sample taken to represent the population is:

$$
\begin{gathered}
n=\frac{315}{1+(315)(0,05)^{2}} \\
n=\frac{315}{1+(0,78)} \\
n=73
\end{gathered}
$$

Based on the above calculations, it can be stated that the number of samples for this study was 73 respondents.

Data collection techniques in this study used literature studies, interviews, and questionnaires, namely by distributing a list of closed statements to predetermined respondents. This is the nurse who executed dr. Soekardjo Hospital, Tasikmalaya. Data processing collected from interviews and questionnaires can be grouped into three steps, namely: preparation, tabulation, and application of data to research approaches. Data analysis techniques using Path Analysis

\section{RESULTS AND DISCUSSION}

Based on the calculation of path analysis, the overall results of the analysis of the influence of organizational culture and compensation for job satisfaction and the implications for the purpose of turnover can be described as follows:

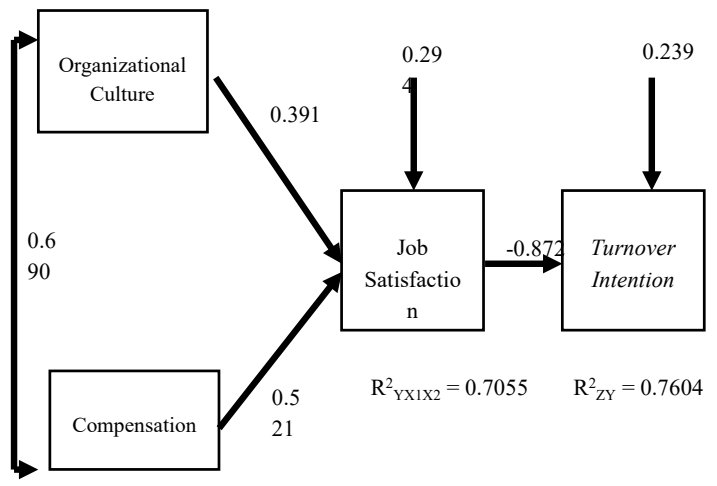

Source: Results of SPSS 25 Statistical Processing

Figure 1. Organizational Culture, Compensation, and Job Satisfaction on Turnover Intentions Model

The research model above (figure 1) shows that organizational learning with compensation has a strong relationship of 0.690 , so that the strength of this relationship has a simultaneous influence on job satisfaction with a determinant coefficient of 0.7055 . While individually the effect of compensation on job satisfaction is 0.521 greater than the effect of organizational culture on job satisfaction which is only 0.391. Meanwhile, individually, job satisfaction has a negative effect on turnover intention, which is -0.872 . This shows that an increase in job satisfaction will have an effect on reducing the level of turnover intention.

Still based on figure 1 above, it can be explained that the path coefficient of each independent variable of job satisfaction and compensation for the dependent variable of job satisfaction, for more details, can be seen in table 1 below:

Table 1. The magnitude of the path coefficient of X1 and $\mathrm{X} 2$ to $\mathrm{Y}$

\begin{tabular}{ccc}
\hline Path Coefficient & $\begin{array}{c}\text { Coefficient } \\
\text { Symbol }\end{array}$ & $\begin{array}{c}\text { Magnitude Path } \\
\text { Coefficien }\end{array}$ \\
\hline $\mathrm{X}_{1}$ to $\mathrm{Y}_{1}$ & $\rho \rho_{\mathrm{YX} 1}$ & 0.391 \\
$\mathrm{X}_{2}$ to $\mathrm{Y}_{1}$ & $\rho \rho_{\mathrm{YX} 2}$ & 0.521 \\
\hline
\end{tabular}

Source: Results of SPSS 25 Statistical Processing

From the table 1 above, equation it can be interpreted that:

1. There is an associative relationship between job satisfaction and organizational culture with a value of 0.391 .

2. There is an associative relationship between compensation and job satisfaction with a value of 0.521 . 
Based on the calculation of the direct and indirect effect of organizational culture (X1) and compensation (X2) on job satisfaction (Y). The results of the calculation can be seen in table 2 below:

Table 2. Direct and Indirect Effects of Organizational Culture (X1) and Compensation (X2) on Job Satisfaction (Y)

\begin{tabular}{cccccc}
\hline \multirow{2}{*}{ Variable } & \multirow{2}{*}{$\begin{array}{c}\text { Direct } \\
\text { Effect }\end{array}$} & \multicolumn{2}{c}{$\begin{array}{c}\text { Indirect Effect } \\
\text { by }\end{array}$} & $\begin{array}{c}\text { Sub Total } \\
\text { Indirect }\end{array}$ & $\begin{array}{c}\text { Influence } \\
\text { Total Effect }\end{array}$ \\
\cline { 3 - 5 } & & $\mathrm{X}_{1}$ & $\mathrm{X}_{2}$ & & \\
\hline $\mathrm{X}_{1}$ & 15.29 & 14.06 & - & 14.06 & 29.35 \\
$\mathrm{X}_{2}$ & 27.14 & - & 14.06 & 14.06 & 41.20 \\
Total Effect & & & & & 70.55 \\
Influence of other factors / residual factors & 29.45 \\
\hline
\end{tabular}

Source: Results of SPSS 25 Statistical Processing

Based on table 2 above, details of the direct and indirect effects together (simultaneously) of organizational culture variables and compensation on job satisfaction, are as following:

1. The magnitude of the partialeffect of organizational culture on satisfaction of work, both directly and indirectly, is the $29,35 \%$.

2. The magnitude of the partial effect of compensation on job satisfaction both direct and indirect effects is $41.20 \%$.

Thus the total influence or joint influence (simultaneously) of the organizational culture variable and compensation on job satisfaction is $70.55 \%$, while the influence of other variables outside the variable is $29.45 \%$. Other variables not examined by the authors that affect job satisfaction include workload.

Based on Figure 1 above, it can be explained the amount of the associative degree or path coefficient of the job satisfaction variable on the variable turnover intention, the path coefficient is -0.872 . The path equation is as follows:

$\mathrm{Z}=-0.872 \mathrm{Y}+\varepsilon 2$

To find out the magnitude of the influence of the job satisfaction variable on turnover intention, we use the analysis of the coefficient of determination, namely the square of the correlation value (r) multiplied by $100 \%$.

$\mathrm{KD}=(\mathrm{r} 2) \times 100 \%$

$\mathrm{KD}=-0.8722 \times 100 \%=76.04 \%$

Variable job satisfaction had an effect on turnover intentions of $76.04 \%$. While the rest of $23,96 \%$ explained by other variables not examined in this study. Job satisfaction has a negative effect on the intention of turnover. This means the Satisfaction of work that contributes at the turn of the -0.872 . This means low job satisfaction, nurse turnover rate a high level of intention and vice versa if the direction of the relationship was positive, the level of intent nurse turnover low. The culture of the organization, according to (Al Mehrzi \& Singh, 2016), is the basic philosophy of an organization that contains the same beliefs, and values that constitute the core characteristics of how to do something in the organization, in which the beliefs, norms, and values to be the instructions of all the human resources in the organization in achieving performance.

According to (S.P. Robbins et al., 2016), the definition of organizational culture is a system of shared meaning held by members that differentiate an organization from other organizations. Referring to Robbins' opinion, every organization is a unique system, so that the organization has its personality and identity. According (Riansari et al., 2012), "Compensation is all forms of payment or gifts for employees and comes from their work. (Gula, 2008) "compensation is the total amount of compensation received by employees instead of services they have provided." (Crane et al., 2016) states that: "Compensation is what a worker receives in return for work given. Either hourly wages or periodic wages are designed and managed by personnel ". (Thanos et al., 2015) states, "compensation is anything that employees receive in return for their work." The issue of compensation is crucial because it is the primary motivation for a person to become an employee and has a significant influence on employees' morale and enthusiasm. Thus, each organization must determine the most appropriate compensation so that it can support achieving its goals more effectively and more efficiently. How much compensation is given must be such that it can bind the employees.

This is very important because if employees' components are too small compared to other companies, this can cause employees to move. (Srivastava \& Kanpur, 2014) define job satisfaction as a feeling of supporting or not supporting employees related to their work or condition. The feelings associated with the work involve aspects such as salary, promotional opportunities, relationships with other employees, job placements, types of corporate organizational structure, and quality of supervision. Meanwhile, feelings associated with including age, health condition, ability, and education. While (Kaur, 2015) The definition of Job Satisfaction is as follows: "job satisfaction is the attitude a person has about their work. It's the result of a perception of their work". Meanwhile, the aspects of labor are wages, opportunities, promotions, supervision, and 
colleagues. It also comes from work environment factors such as policies and procedures, affiliate working groups, and working conditions. (Liden et al., 2014) states that most employees who leave the company for voluntary reasons can be categorized as avoidable voluntary turnover and unavoidable voluntary turnover. Avoidable voluntary turnover can be caused for reasons such as salary, working conditions, employers, or other companies that feel better. On the contrary, unavoidable voluntary turnover can be caused by changes in career paths or family factors. (Chen \& Silverthorne, 2005), the turnover intention is the intensity of the desire to leave the company. The intention to leave is defined as a person's intention to make an actual separation (turnover) from an organization (Mosadeghrad, 2013). Meanwhile, (De Simone et al., 2018) states that the intention of turnover refers to the results of the evaluation of individuals regarding the continuation of their relationship with the organization and has not been manifested in the definite action of leaving the organization.

Factors affecting turnover are nurse divided into two, namely nurse characteristics (age, gender, family background, work experience, motivation, nurse typology, and self-perception) and internal hospital environmental factors (HR management which includes recruitment and selection, socialization, training and development, job performance appraisal, system reward, promotion, transfer and termination of employment, as well as organizational culture, and work comfort (Priatna \& Roswinna, 2019). This is also said by (Halbesleben \& Wheeler, 2008) that the problem of human resources which is often an indicator of the effectiveness of an organization is turnover. If threat turnover increases, it is necessary to evaluate whether this is due to poor workplace conditions or due to other factors. One of the turnover high rates in the health care industry, in this case the hospital, occurs in nurses because nurses are one of the largest personnel in the hospital. According to (De Simone et al., 2018), the standard of turnover optimum of nurses in a hospital is $10 \%$ annually. The high turnover of nurses is due to the high turnover intention of nurses to leave the hospital where this desire is influenced by job satisfaction and the availability of job alternatives outside the organization (Marina et al., 2014).

\section{CONCLUSION}

The descriptive analysis showed that in the culture of the General organization and compensation is in the category of poor as well as the job satisfaction and turnover goals in general, categorized as less good, less satisfied and high basically, most of the respondents replied to all statements a score between 3 and 4. This indicates that the respondents answered the criteria enough and better, so that the response of the respondents is quite positive or responsive. So, the average Ratings of all respondents on all items questions provide an assessment that is good enough. However, this response was still below the score 4 and Score 5. This suggests that the response to the various question items are not optimal. The influence of organizational culture and compensation on job satisfaction simultaneously the most and job satisfaction simultaneously have a negative effect on the purpose of the turnover in the Regional General Hospital Dr. Soekardjo Tasikmalaya. The results of the research, both simultaneously and partially, organizational culture and compensation have an effect on nurses 'job satisfaction, so to keep nurses' job satisfaction high, the hospital should continue to maintain and pay attention to aspects of organizational culture and compensation. Job satisfaction has an effect on turnover intention which leads negatively, so the hospital is expected to maintain and increase the job satisfaction of nurses to reduce the turnover intention of nurses by reviewing the salary system and the appropriateness of the amount of salary with workload, reviewing employee health benefits, taking rights system. leave, as well as increase education for career development. This research is only part of the factors that affect job satisfaction and turnover intention. When viewed from (other factors that affect job satisfaction and turnover intention) are still quite large, including workload and leadership. These factors can be investigated further by the next researcher.

\section{REFERENCES}

Al Mehrzi, N. \& Singh, S.K. (2016). Competing through employee engagement: a proposed framework. International Journal of Productivity and Performance Management, 65, (6), 831-843. https://doi.org/10.1108/ IJPPM-02-2016-0037

Baker, W.E. \& Sinkula, J.M. (2009). Orientation and Entrepreneurial Orientation. Journal of Small Business Management, 47, (4), 443-464. https://doi.org/10.1111/j.1540627X.2009.00278.X

Baumann, A. (2010). The Impact of Turnover and the Benefit of Stability in the Nursing Workforce. Switzerland: International Counsil of Nurses

Chen, J.C. \& Silverthorne, C. (2005). Leadership effectiveness, leadership style and employee readiness. Leadership and Organization 
Development Journal, 61, (3), 514-520. https://doi.org/10.1108/01437730510600652

Chitpakdee B. \& Chontawan R. (2011). Factors Predicting Organizational Commitment among Nurses in State Hospitals, Malaysia. International Journal of Organizational analysis, 19, (2), 146-170.

Chu, J., Leino, A., Pflum, S. \& Sue, S. (2016). Amodel for the theoretical basis of cultural competency to guide psychotherapy. Professional Psychology: Research and Practice, 47, (1), 18-29. https://doi.org/10.1037/pro0000055

Chung, C.E.E. (2011). Job stress, mentoring, psychological empowerment, and job satisfaction among nursing faculty. Job Stress, Mentoring, Psychological Empowerment \& Job Satisfaction Among Nursing Faculty, 46, (5), 13-21.https://doi.org/10.3928/0148483420120509-03

Crane, A.D., Michenaud, S. \& Weston, J.P. (2016). The Effect of Institutional Ownership on Payout Policy: Evidence from Index Thresholds. In Review of Financial Studies, 11, (6), 34-44. https://doi.org/10.1093/rfs/hhw012

De Simone, S., Planta, A. \& Cicotto, G. (2018). The role of job satisfaction, work engagement, self-efficacy and agentic capacities on nurses' turnover intention and patient satisfaction. Applied Nursing Research, 21, (13), 83-95. https://doi.org/10.1016/j.apnr.2017.11.004

Gula, R. (2008). Legal protection of wolves in Poland: Implications for the status of the wolf population. European Journal of Wildlife Research, 15, (7), 65-76. https://doi. org/10.1007/s10344-007-0129-8

Halbesleben, J.R.B. \& Wheeler, A.R. (2008). The relativerolesofengagementandembeddedness in predicting job performance and intention to leave. Work and Stress, 21, (18), 113-121. https://doi.org/10.1080/02678370802383962

Kaur, C. (2015). Quality Of Work Life: A Key To Improve Organizational Performance. Sajems Ns, 13, (4), 12-22.

Liden, R.C., Wayne, S.J., Liao, C. \& Meuser, J.D. (2014). Servant leadership and serving culture: Influence on individual and unit performance. Academy of Management Journal, 36, (7), 251-263. https://doi. org/10.5465/amj.2013.0034

Marina, A., Sugeng, B., Wahyono, H. \& Nirbito, J. G. (2014). Economic literacy for the basis of organizational performance improvement: evidence from Muhammadiyah hospital Indonesia. Journal of Asian Scientific Research, 21, (10), 33-45.

Mosadeghrad, A.M. (2013). Occupational stress and turnover intention: Implications for nursing management. International Journal of Health Policy and Management, 66, (12), 25132525. https://doi.org/10.15171/ijhpm.2013.30

Pemerintah Republik Indonesia. (2014). Peraturan Pemerintah Republik Indonesia Nomor 101 Tahun 2014 tentang Pengelolaan Limbah Bahan Berbahaya dan Beracun. Pediatric Physical Therapy.

Priatna, D. K. \& Roswinna, W. (2019). Influence leadership motivation and performance of employees at Bank Rakyat Indonesia Subang Branch Office. Test Engineering and Management, 16, (3), 41-51.

Riansari, T., Sudiro, A. \& Rofiaty. (2012). Pengaruh Kompensasi dan Lingkungan Kerja terhadap Kepuasan Kerja dan Kinerja Karyawan ( Studi Kasus PT Bank TabunganPensiunan Nasional , Tbk. Cabang Malang ). Jurnal Aplikasi Manajemen TERAKREDITASI SK DIRJEN DIKTI NO. 66b/DIKTI/KEP/2011.

Robbins, S.P. \& Judge, T.A. (2008). Perilaku organisasi edisi ke-12. Chemical and Petroleum Engineering.

Robbins, S.P., Judge, T.A., Odendaal, A., \& Roodt, G. (2016). Organisational behaviour: Global and Southern African Perspectives. Pearson South Africa (Pty) Ltd.

Srivastava, S. \& Kanpur, R. (2014). A Study On Quality Of Work Life: Key Elements \& It's Implications. IOSR Journal of Business and Management, 36, (7), 55-68. https://doi. org/10.9790/487x-16315459

Thanos, C.A., Pangemanan, S.S. \& Rumokoy, F.S. (2015). the Effect of Job Satisfaction and Employee Motivation on Employee Loyalty (case Study of Pt Kimia Farma Apotek in Sam Ratulangi, Manado). Jurnal Berkala Ilmiah Efisiensi. 15, (04).

Umar, H. (2008). Metode penelitian untuk penulisan skripsi dan tesis. PPM Manajemen.

Williams, C. C., \& Nadin, S. (2012). Entrepreneurship in the informal economy: Commercial or social entrepreneurs? International Entrepreneurship and Management Journal, Vol. 47 No. 17, pp. 441-452. https://doi.org/10.1007/s11365-011-0169-0 